\title{
Cloning and Human Dignity
}

\author{
JOHN HARRIS
}

The panic occasioned by the birth of Dolly sent international and national bodies and their representatives scurrying for principles with which to allay imagined public anxiety. It is instructive to note that principles are things of which such people and bodies so often seem to be bereft. The search for appropriate principles turned out to be difficult since so many aspects of the Dolly case were unprecedented. In the end, some fascinating examples of more or less plausible candidates for the status of moral principles were identified; central to many of them is the idea of human dignity and how it might be affected by human mitotic reproduction. ${ }^{1}$

Typical of appeals to human dignity was that contained in the World Health Organization statement on cloning issued on 11 March 1997:

WHO considers the use of cloning for the replication of human individuals to be ethically unacceptable as it would violate some of the basic principles which govern medically assisted procreation. These include respect for the dignity of the human being. ... .

Appeals to human dignity are, of course, universally attractive; they are also comprehensively vague. A first question to ask when the idea of human dignity is invoked is: whose dignity is attacked and how? If it is the duplication of a large part of the human genome that is supposed to constitute the attack on human dignity, or where the issue of "genetic identity" is invoked, we might legitimately ask whether and how the dignity of a natural twin is threatened by the existence of her sister and what follows as to the permissibility of natural monozygotic twinning? However, the notion of human dignity is often linked to Kantian ethics and it is this link I wish to examine more closely here.

A typical example, and one that attempts to provide some basis for objections to cloning based on human dignity, was Axel Kahn's invocation of this principle in his commentary on cloning in Nature. Kahn, a distinguished molecular biologist, helped draft the French National Ethics Committee's report on cloning. In Nature Kahn states:

The creation of human clones solely for spare cell lines would, from a philosophical point of view, be in obvious contradiction to the principle expressed by Emmanuel Kant: that of human dignity. This principle demands that an individual-and I would extend this to read human life-should never be thought of as a means, but always also as an end. Creating human life for the sole purpose of preparing therapeutic material would clearly not be for the dignity of the life created. $^{2}$ 


\section{John Harris}

The Kantian principle, invoked without any qualification or gloss, is seldom helpful in medical or bioscientific contexts. ${ }^{3}$ As formulated by Kahn, for example, it would surely outlaw blood transfusions. The beneficiary of blood donation, neither knowing of, nor usually caring about, the anonymous donor uses the blood (and its donor) exclusively as a means to her own ends. The blood in the bottle has after all less identity, and is less connected with the individual from which it emanated, than the chicken "nuggets" on the supermarket shelf. An abortion performed exclusively to save the life of the mother would also, presumably, be outlawed by this principle.

\section{Instrumentalization}

This idea of using individuals as a means to the purposes of others is sometimes termed "instrumentalization," particularly in the European context. The advisers to the European Commission on the ethical implications of biotechnology, for example, in their statement on ethical aspects of cloning techniques use this idea repeatedly. ${ }^{4}$ Referring to reproductive human cloning, paragraph 2.6 states:

Considerations of instrumentalization and eugenics render any such acts ethically unacceptable.

Applying this idea coherently or consistently is not easy! If someone wants to have children in order to continue their genetic line do they act instrumentally? Where, as is standard practice in IVF, spare embryos are created, are these embryos created instrumentally?

Kahn responded in the journal Nature to these objections. ${ }^{5}$ He reminds us, rightly, that Kant's famous principle states: "respect for human dignity requires that an individual is never used ... exclusively as a means" and suggests that I have ignored the crucial use of the term "exclusively." I did not, of course, and I'm happy with Kahn's reformulation of the principle. It is not that Kant's principle does not have powerful intuitive force, but that it is so vague and so open to selective interpretation and its scope for application is consequently so limited that its utility as one of the "fundamental principles of modern bioethical thought," as Kahn describes it, is virtually zero.

Kahn himself rightly points out that debates concerning the moral status of the human embryo are debates about whether embryos fall within the scope of Kant's or indeed any other moral principles concerning persons; so the principle itself is not illuminating in this context. Applied to the creation of individuals who are, or will become autonomous, it has limited application. True, the Kantian principle rules out slavery, but so do a range of other principles based on autonomy and rights. If you are interested in the ethics of creating people, then, so long as existence is in the created individual's own best interests, and the individual will have the capacity for autonomy like any other, the motives for which the individual was created are either morally irrelevant or subordinate to other moral considerations. So that even where, for example, a child is engendered exclusively to provide "a son and heir" (as is often the case in many cultures) it is unclear how or whether Kant's principle applies. Either other motives are also attributed to the parent to square parental purposes with Kant, or the child's eventual autonomy and its clear and substantial interest in 


\section{Cloning and Human Dignity}

or benefit from existence take precedence over the comparatively trivial issue of parental motives. Either way the "fundamental principle of modern bioethical thought" is unhelpful.

It is therefore strange that Kahn and others invoke it with such dramatic assurance or how anyone could think that it applies to the ethics of human cloning. It comes down to this: Either the ethics of human cloning turn on the creation or use of human embryos, in which case as Kahn himself says "in reality the debate is about the status of the human embryo" and Kant's principle must wait upon the outcome of that debate; or, it is about the ethics of producing clones who will become autonomous human persons. In this latter case, as David Shapiro also comments, ${ }^{6}$ the ethics of their creation are, from a Kantian perspective, not dissimilar to other forms of assisted reproduction, or, as I have suggested, to the ethics of the conduct of parents concerned exclusively with producing an heir, or preserving their genes, or, as is sometimes alleged, making themselves eligible for public housing. Debates about whether these are exclusive intentions can never be definitively resolved.

Kahn then produces a bizarre twist to the argument from autonomy. He defines autonomy as "the indeterminability of the individual with respect to external human will" and identifies it as one of the components of human dignity. This is, of course, hopeless as a definition of autonomy-those in persistent vegetative state (PVS) and indeed all newborns would on such a view have to count as autonomous! However, Kahn then asserts:

The birth of an infant by asexual reproduction would lead to a new category of people whose bodily form and genetic make-up would be exactly as decided by other humans. This would lead to the establishment of an entirely new type of relationship between the "created" and the "creator" which has obvious implications for human dignity.

Kahn is, I'm afraid, wrong on both counts. As Robert Winston has noted: "even if straight cloning techniques were used, the mother would contribute important constituents-her mitochondrial genes, intrauterine influences and subsequent nurture." 7 These, together with the other influences, would prevent exact determination of bodily form and genetic identity. For example, differences in environment, age, and anno domini between clone and cloned would all come into play.

Lenin's embalmed body lies in its mausoleum in Moscow. Presumably a cell of this body could be denucleated and Lenin's genome cloned. Could such a process make Lenin immortal and allow us to create someone whose bodily form and genetic makeup, not to mention his character and individuality, would be "exactly as decided by other human beings?" I hope the answer is obvious. Vladimir Ilyich Ulyanov was born on 10 April 1870 in the town of Simbirsk on the Volga. It is this person who became and who is known to most of us as V.I. Lenin. Even with this man's genome preserved intact we will never see Lenin again. So many of the things that made Vladimir Ilyich what he was cannot be reproduced, even if his genome can. We cannot recreate prerevolutionary Russia. We cannot simulate his environment and education; we cannot recreate his parents to bring him up and influence his development so profoundly as they undoubtedly did. We cannot make the thought of Karl Marx seem as hopeful as it must then have been; we cannot, in short, do anything but 


\section{John Harris}

reproduce his genome and that could never be nearly enough. It may be that "manners maketh man" but genes most certainly do not.

As we know from monozygotic twins, autonomy is unaffected by close similarity of bodily form and matching genome. The "indeterminability of the individual with respect to external human will" will remain unaffected by cloning. Where then are the obvious implications for human dignity?

When Kahn asks: "is Harris announcing the emergence of a revisionist tendency in bioethical thinking?" the answer must be, rather, I am pleading for the emergence of "bioethical thinking" as opposed to the empty rhetoric of invoking resonant principles with no conceivable or coherent application to the problem at hand.

Clearly, the birth of Dolly and the possibility of human equivalents have left many people feeling not a little uneasy, if not positively queasy at the prospect. It is perhaps salutary to remember that there is no necessary connection between phenomena, attitudes, or actions that make us uneasy, or even those that disgust us, and those phenomena, attitudes, and actions that there are good reasons for judging unethical. Nor does it follow that those things we are confident are unethical must be prohibited by legislation or controlled by regulation. These are separate steps that require separate arguments.

\section{Moral Nose}

The idea that moral sentiments, or indeed, gut reactions must play a crucial role in the determination of what is morally permissible is tenacious. This idea, originating with David Hume (who memorably remarked that morality is "more properly felt than judg'd of"), has been influential in the work of a number of contemporary moral philosophers. ${ }^{8}$ In particular, Mary Warnock has made it a central part of her own approach to these issues. Briefly the idea is:

If morality is to exist at all, either privately or publicly, there must be some things which, regardless of consequences should not be done, some barriers which should not be passed.

What marks out these barriers is often a sense of outrage, if something is done; a feeling that to permit some practice would be indecent or part of the collapse of civilisation. ${ }^{9}$

A recent, highly sophisticated and thoroughly mischievous example in the context of cloning comes from Leon R. Kass. In a long discusssion entitled "The Wisdom of Repugnance" Kass tries hard and thoughtfully to make plausible the thesis that thoughtlessness is a virtue:

We are repelled by the prospect of cloning human beings not because of the strangeness or novelty of the undertaking, but because we intuit and feel, immediately and without argument, the violation of things that we rightfully hold dear. ${ }^{10}$

The difficulty is, of course, to know when one's sense of outrage is evidence of something morally disturbing and when it is simply an expression of bare prejudice or something even more shameful. The English novelist George Orwell once referred to this reliance on some innate sense of right and wrong as "moral nose," as if one could simply sniff a situation and detect wickedness. ${ }^{11}$ 


\section{Cloning and Human Dignity}

The problem, as I have indicated, is that nasal reasoning is notoriously unreliable, and olfactory moral philosophy, its theoretical "big brother," has done little to refine it or give it a respectable foundation. We should remember that in the recent past, among the many discreditable uses of so-called "moral feelings," people have been disgusted by the sight of Jews, black people, and indeed women being treated as equals and mixing on terms of equality with others. In the absence of convincing arguments, we should be suspicious of accepting the conclusions of those who use nasal reasoning as the basis of their moral convictions.

In Kass's suggestion (he disarmingly admits revulsion "is not an argument") the giveaway is in his use of the term "rightfully." How can we know that revulsion, however sincerely or vividly felt, is occasioned by the violation of things we rightfully hold dear unless we have a theory, or at least an argument, about which of the things we happen to hold dear we rightfully hold dear? The term "rightfully" implies a judgment that confirms the respectability of the feelings. If it is simply one feeling confirming another, then we really are in the situation Wittgenstein lampooned as buying a second copy of the same newspaper to confirm the truth of what we read in the first.

We should perhaps also note for the record that cloning was not anticipated by the Deity in any of his (or her) manifestations on earth; nor in any of the extant holy books of the various religions. Ecclesiastical pronouncements on the issue cannot therefore be evidence of God's will on cloning, and must be examined on the merits of the evidence and argument that inform them, like the judgments or opinions of any other individuals.

\section{Notes}

1. For a more comprehensive account of the ethics of human cloning generally see Harris J. Goodbye Dolly? the ethics of human cloning. Journal of Medical Ethics 1997;23(6).

2. Kahn A. Clone mammals ... clone man. Nature 1997;386:119.

3. Harris J. Is cloning an attack on human dignity? Nature 1997;387:754.

4. GAEIB. Opinion of the group of advisers on the ethical implications of biotechnology to the European Commission, No. 9. 28 May 1997.

5. See note 2, Kahn 1997.

6. Shapiro D. Letter. Nature 1997;388:511.

7. Winston R. British Medical Journal 1997;314:913-4.

8. David Hume in his A Treatise of Human Nature 1738. Contemporary philosophers who have flirted with a similar approach include Stuart Hampshire; see, for example, Hampshire S. Morality \& Pessimism: The Leslie Stephen Lecture. Cambridge: Cambridge University Press, 1972; and Bernard Williams in Against utilitarianism. In Williams B, Smart JCC. Utilitarianism For and Against. Cambridge: Cambridge University Press, 1973. I first discussed the pitfalls of olfactory moral philosophy in my Violence and Responsibility. London: Routledge \& Kegan Paul, 1980.

9. Warnock M. Do human cells have rights? Bioethics 1987;1(1):8.

10. Kass LR. The wisdom of repugnance. The New Republic 1997;Jun 2:17-26. The obvious erudition of his writing leads to expectations that he might have found feelings prompted by more promising parts of his anatomy with which to entertain us.

11. Orwell G. Letter to Humphrey House (11 April 1940). The Collected Essays, Journalism and Letters of George Orwell, vol.1. Harmondsworth: Penguin, 1970:583. See my more detailed discussion of the problems with this type of reasoning in Harris J. Wonderwoman \& Superman: The Ethics of Human Biotechnology. Oxford: Oxford University Press, 1992. 